\title{
Leucine degradation in sheep
}

\author{
BY W. G. BERGEN, J. R. BUSBOOM* AND R. A. MERKEL \\ Department of Animal Science, Growth Biology Program, Michigan State University, \\ East Lansing, MI 48824, USA
}

(Received 30 June 1987 - Accepted 27 October 1987)

\begin{abstract}
1. In vitro leucine catabolism in adipose tissue, skeletal muscle, kidney and liver homogenates was studied in sheep.

2. In Expt 1, Suffolk $\times$ Targhee ram lambs were slaughtered at 1, 28, 56, 84, 112, 140, 168, 196, 224 and $365 \mathrm{~d}$ of age. In Expt 2, 5-month-old crossbred wethers were fed on 80,120 or $180 \mathrm{~g}$ crude protein (nitrogen $\times 6.25$ ) $/ \mathrm{kg}$ diets for 4 weeks or fed on $120 \mathrm{~g}$ crude protein $/ \mathrm{kg}$ for 4 weeks and then fasted for 48 or $96 \mathrm{~h}$ before slaughter. Leucine catabolism was assayed in tissue homogenates for Expts 1 and 2.

3. Leucine deamination (per unit protein) was highest in skeletal muscle at day 1 and then declined; liver exhibited an activity pattern akin to muscle while kidney activity tended to rise over the duration of the study. Adipose tissue in vitro leucine deamination was higher at all ages studied and 9- to 50-fold higher than all other tissues at $365 \mathrm{~d}$. Leucine decarboxylation (per unit protein) was highest at day 1 in muscle and declined to low levels $(P<0.01)$ after $28 \mathrm{~d}$; liver and kidney decarboxylation activities were higher than muscle at all ages with kidney showing the highest activity. Whilst adipose had high initial activity it declined significantly $(P<0 \cdot 01)$ by day 28 and remained low.

4. Dietary protein intake had no effect on leucine deamination in any tissue. Leucine decarboxylation tended to increase with protein intake for all tissues except kidney. Length of fast $(96 \mathrm{~h})$ resulted in a variable decline in leucine deamination; leucine decarboxylation was significantly lower in kidney, liver and adipose tissue after a $96 \mathrm{~h}$ fast.

5. When these in vitro enzyme activity results are related to questions concerning the role of skeletal muscle in leucine catabolism in sheep, the present findings indicate that in grown sheep, skeletal muscle has a small to moderate role in total body leucine deamination but plays a very minor role in leucine decarboxylation. Adipose tissue appears to be a major site of leucine deamination in grown sheep. These results are not in agreement with the idea that during fasting leucine becomes an important energy substrate and is oxidized in skeletal muscle as has been shown in rodents.
\end{abstract}

Skeletal muscle appears to be an important site of branched-chain amino acid (BCAA) catabolism (at least transamination) and of synthesis of alanine and glutamine in man and rodents (Harper et al. 1984). Rapid degradation of all three BCAA (leucine, valine and isoleucine) and consequent synthesis of dispensible amino acids, especially alanine, glutamine and glutamic acid, have been demonstrated in isolated rat diaphragm and skeletal muscle incubated in vitro (Goldberg \& Odessey, 1972; Chang \& Goldberg, $1978 a, b)$.

Catabolism of BCAA is a two-step process. Initially the BCAA is deaminated by an aminotransferase to its corresponding branched-chain 2-oxo-acid. The oxo-acid is then decarboxylated by a branched-chain 2-oxo-acid deyhdrogenase. Harper et al. (1984) have demonstrated that in rats aminotransferase activity is high in skeletal muscle while the dehydrogenase activity is predominant in liver. A potentially important role in leucine degradation by adipose tissue in rats has been identified by Tischler \& Goldberg (1980).

There is some evidence that the role of skeletal muscle in BCAA catabolism in ruminants may be more limited than that in rodents and man (Ballard et al. 1976; Lindsay \& Buttery, 1980; Ahmed et al. 1983; Teleni et al. 1983). This conclusion is based on studies with sheep and cattle, employing whole-animal studies measuring blood flows and venous-arterial

* Present address: Department of Animal Science, University of Wyoming, Laramie, Wyoming 87071, USA. 
amino acid differences across various tissues. More recently it was shown with pregnant ewes and fetal sheep that BCAA aminotransferase (EC 2.6.1.42) activities were quite low in maternal skeletal muscle, low in fetal and maternal liver, high in fetal muscle and very high in placenta (Goodwin et al. 1987). Branched-chained 2-oxo acid deyhdrogenase (EC 1.2.4.4) total activity was highest for liver and kidney in both ewes and fetuses, while skeletal muscle total activity was less than $10 \%$ of liver and kidney values (Goodwin $e t$ al. 1987).

The present study was initiated to assess the enzymic capacity of skeletal muscle, liver, kidney and adipose tissue of sheep for leucine trans(de)amination and decarboxylation.

Results of the present study indicate that in mature sheep, adipose tissue has the highest leucine trans(de)amination activity (expressed as pmol metabolized/mg tissue protein per $\mathrm{min}$ ) while skeletal muscle had low leucine trans(de)amination activity and very-low leucine decarboxylation activity.

\section{MATERIALS AND METHODS}

Two separate experiments were carried out to study in vitro leucine catabolism by adipose tissue, skeletal muscle, kidney and liver of sheep.

\section{Experimental design}

Expt 1. Forty-nine Suffolk $\times$ Targhee ram lambs reared at the Sheep Teaching and Research Centre, Michigan State University, were killed at 1, 28, 56, 84, 112, 140, 168, 196, 224 or $365 \mathrm{~d}$ of age. Five lambs were killed at each of the ages except four lambs were killed at day 365. The 84- to 365-d-old lambs were born in March of 1982, and the 1- to 56-dold lambs were born in March of 1983. During 1983, an additional four lambs were slaughtered on day 84 . Both groups of lambs were from the same Targhee ewe flock and were sired by Suffolk rams of similar breeding. All lambs were offered additional feed (creep diet) to be consumed ad lib. during the suckling period $(60 \mathrm{~d})$ and were then fed ad lib. on a complete diet for the remaining experimental period. Water was available at all times. Lambs scheduled for slaughter were fasted overnight $(12 \mathrm{~h})$ before slaughter while 1-d-old lambs were removed from their dams and slaughtered after approximately $4 \mathrm{~h}$. All sheep were slaughtered at the Michigan State University Meat Laboratory.

Expt 2. Crossbred wether lambs (5 months old) were obtained from a single commercial source and adjusted to feeding $a d$ lib. on a 120 g crude protein (nitrogen $\times 6.25$; CP; Table 1) $/ \mathrm{kg}$ diet over a 1-week period. The sheep were then weighed and assigned to five treatments for a 4 week experimental feeding period. Five lambs were assigned to each of the following five protein levels or fasting treatment groups: (1) lambs fed on 80, (2) 120 or (3) $180 \mathrm{~g} \mathrm{CP} / \mathrm{kg}$ diets (Table 1) for 4 weeks or lambs fed on the $120 \mathrm{~g} \mathrm{CP} / \mathrm{kg}$ diet for 4 weeks and then fasted for either (4) 48 or (5) $96 \mathrm{~h}$ before slaughter. Feed was removed $12 \mathrm{~h}$ (overnight) before slaughter for lambs on the three diets of different protein levels. To avoid a treatment $\times$ day interaction, one lamb from each treatment group was slaughtered on each of five consecutive slaughter days.

\section{Diets}

Expt 1. During the suckling period all lambs were fed on the following creep diet $(\mathrm{g} / \mathrm{kg})$ : dehydrated lucerne (Medicago sativa) 380, ground maize $286 \cdot 5$, rolled oats 100 , soya-bean meal 120 , molasses 70 , dicalcium phosphate 5 , trace mineral salt (with $30 \mu \mathrm{g} \mathrm{Se} / \mathrm{g}$ ) $3 \cdot 5$, ammonium chloride 35 , until weaning at $60 \mathrm{~d}$ of age. Lambs were then adjusted to ad lib. feeding of the experimental diet containing $(\mathrm{g} / \mathrm{kg})$ : deyhydrated lucerne 380 , ground maize 295 , ground wheat 100 , rolled oats 80 , soya-bean meal 60 , molasses 70 , dicalcium 
Table 1. Composition of experimental diets* $(\mathrm{g} / \mathrm{kg})$

\begin{tabular}{lrrr}
\hline \multicolumn{1}{c}{$\begin{array}{c}\text { Crude protein } \\
\text { (nitrogen } \times 6 \cdot 25 \text { ) } \mathrm{g} / \mathrm{kg} \text { diet } \dagger \ldots\end{array}$} & 80 & \multicolumn{1}{c}{120} & 180 \\
\hline Maize, ground & 670 & 640 & 520 \\
Oats, rolled & 200 & 200 & 180 \\
Molasses & 50 & 50 & 50 \\
Trace mineral salt $\ddagger$ & 20 & 20 & 20 \\
Limestone & 10 & 10 & 10 \\
Glucose monohydrate & 44 & - & - \\
Soya-bean & -5 & 75 & 215 \\
Ammonium chloride & 5 & 5 & 5 \\
\hline \hline
\end{tabular}

* Balanced to (US) National Research Council (1975) recommended calcium, phosphorus intakes; no fatsoluble vitamins were added.

$\dagger$ Composition given on an air-dry basis.

$\ddagger$ Contained $(\mathrm{mg} / \mathrm{kg})$ : iron 20 , manganese 27 , zinc 35 , copper 30 , cobalt 5 , iodine 7 , with a minimum of 960 to a maximum of 985 sodium chloride.

phosphate 5 , limestone 5 , trace mineral salt 5 . The trace mineral salt contained a minimum of $(\mathrm{mg} / \mathrm{kg})$ : iron 20 , manganese 20 , zinc 35 , copper 30 , cobalt 5 , iodine 7 , with a minimum of 960 and a maximum of $985 \mathrm{~g}$ sodium chloride $/ \mathrm{kg}$.

Expt 2. Sheep were fed on the experimental diets presented in Table 1.

\section{Tissue preparation}

At slaughter longissimus and trapezius muscles, liver and kidney samples were rapidly excised and placed in ice-cold $15 \mathrm{~mm}$-potassium phosphate homogenization buffer (pH 7.5) containing $0.25 \mathrm{M}$-sucrose, $3 \mathrm{~mm}$-magnesium chloride and $1 \mathrm{~mm}$-EGTA. The tissues were minced wtih scissors, passed through a cold tissue-press (Harvard Apparatus Co. Inc., Dover, MA) and $1.25 \mathrm{~g}$ of the tissue preparation were suspended in $10 \mathrm{ml}$ of the homogenization buffer ( $\mathrm{pH} \mathrm{7.5)}$ containing glycerol $(500 \mathrm{ml} / \mathrm{l})$. The suspensions were homogenized in Potter-Elvehjem ground-glass homogenizing tubes with a motor-driven Teflon pestle. Homogenates were then strained through a single layer of cheesecloth, sealed in screw-capped test-tubes and frozen in acetone cooled with dry ice $\left(-70^{\circ}\right)$ for assay later the same day. Perirenal adipose tissue samples were removed from the 1-d-old lambs (Expt 1), and subcutaneous adipose tissue samples were excised from the dorsal surface of the 6th-12th thoracic vertebrae region of all other lambs in both Expts 1 and 2. These adipose tissue samples were handled identically to the muscle, liver and kidney samples except that they were placed in buffer at room temperature and homogenized. Buffer at room temperature was used for more efficient homogenization of adipose tissues because at icecold temperature homogenization was difficult to accomplish. In preliminary studies we found that assayable leucine degradation activities in these two adipose tissues were not affected by homogenization temperature (Busboom, 1984). Perirenal adipose tissue was removed at day 1 because neonatal lambs had insufficient subcutaneous fat.

\section{Leucine catabolism in vitro}

$\mathrm{L}-\left[1-{ }^{14} \mathrm{C}\right]$ leucine was used as a tracer to measure leucine transamination and decarboxylation of tissue homogenates in vitro. These measurements reflect leucine aminotransferase (EC 2.6.1.6) and 4-methyl 2-oxopentanoic acid dehydrogenase (EC1.2.4.4) activities but the latter will not be referred to as such since the tissue 
homogenates were employed as sources of enzymes in the present study and the specific substrate for the dehydrogenase, e.g. 4-methyl 2-oxopentanoic acid, was not used.

The tissue homogenate assay system was patterned after Wagenmakers \& Veerkamp (1982) and was similar to the procedures of Kasperek et al. (1985). Frozen homogenates in screw-capped test-tubes were thawed for $2 \mathrm{~min}$ in a water-bath at $37^{\circ}$. Subsequently, 0.5 $\mathrm{ml}$ homogenate was added to $1.9 \mathrm{ml}$ assay medium contained in a side-arm reaction flask (Kontes, Vineland, NJ). The homogenates were pre-incubated in triplicate at $37^{\circ}$ for $15 \mathrm{~min}$ and then a $20 \mathrm{~min}$ reaction period was initiated by the addition of $0 \cdot 2 \mu \mathrm{Ci} \mathrm{L}-\left[1-{ }^{14} \mathrm{C}\right]$ leucine $(40 \mathrm{mCi} / \mathrm{mol})$ in $100 \mu \mathrm{l}$ buffer. The final concentration in the reaction buffer, cofactors and substrate were $0.2 \mathrm{~mm}$-thiamin pyrophosphate, $2.5 \mathrm{mM}-\mathrm{MgCl}_{2}, 0.5 \mathrm{mM}-\mathrm{NAD}^{+}, 0.2 \mathrm{mM}-$ EGTA, 2 mM-2-oxo-glutarate, $1 \mathrm{~mm}$-dithiothreitol, $50 \mathrm{~mm}$-sucrose, $2 \mathrm{~mm}$-leucine and 15 mM-potassium phosphate ( $\mathrm{pH} 7.5$ ) in a total volume of $2.5 \mathrm{ml}$. Coenzyme $\mathrm{A}$ is usually a required cofactor for more-purified enzyme sources, but the inclusion of coenzyme $A$ in this assay did not affect leucine decarboxylation (Busboom, 1984). A similar absence of a coenzyme A requirement has been observed by others (Odessey \& Goldberg, 1979). Blanks containing the entire reaction mixture, with the exception of the homogenized tissues, were run simultaneously.

In these experiments the potential capacity (maximum activity) for leucine catabolism was to be assessed in ovine tissues. Thus tissue homogenates were pre-incubated for $15 \mathrm{~min}$ in the presence of $\mathrm{MgCl}_{2}$ to deplete tissue ATP and cause dephosphorylation (activation) of branched-chain 2-oxo-acid deyhdrogenase (Harper et al. 1984; Goodwin et al. 1987). Following addition of $\left[{ }^{14} \mathrm{C}\right]$ leucine, the flasks were immediately capped and shaken at 60 rev./min. At the end of $20 \mathrm{~min}, 0.5 \mathrm{ml} 2 \mathrm{M}$-sulphuric acid was injected through the side-arm serum-rubber stopper to stop the reaction and release all ${ }^{14} \mathrm{CO}_{2}$ produced from the media. The ${ }^{14} \mathrm{CO}_{2}$ was subsequently collected for $1 \mathrm{~h}$ with continuous shaking in $0 \cdot 3 \mathrm{ml}$ ethylene glycol monomethyl ether-ethanolamine $(12: 1, \mathrm{v} / \mathrm{v})$ which was suspended in a centre-well trap (Kontes). The traps were then removed, placed in scintillation vials containing $10 \mathrm{ml}$ of an aqueous counting fluid (Amersham, Arlington Heights, IL), and radioactivity was counted by liquid scintillation. Following removal of the traps, the reaction flasks were recapped and the carboxyl-carbons of the 4-methyl 2-oxopentanoate in the media were non-enzymically cleaved by the addition of $3 \mathrm{ml} 4 \mathrm{M}-\mathrm{H}_{2} \mathrm{SO}_{4}$ saturated with ceric sulphate. The ${ }^{14} \mathrm{CO}_{2}$ thus cleaved was again trapped in ethylene glycol monomethyl etherethanolamine and counted as described previously for the $2 \mathrm{M}-\mathrm{H}_{2} \mathrm{SO}_{4}$-released ${ }^{14} \mathrm{CO}_{2}$. The initial ${ }^{14} \mathrm{CO}_{2}$ collection represents total enzymic decarboxylation of leucine (assayable branched-chain 2-oxo acid dehydrogenase activity). The sum of the two ${ }^{14} \mathrm{CO}_{2}$ collections is a measure of leucine transamination.

Homogenates of kidney, liver and semimembranosus (SM) muscles of mature sheep (over 1 year of age) were utilized to characterize the effect of time-period of incubation, role of substrate (leucine) concentration, cryogenic freezing in glycerol $(500 \mathrm{ml} / 1)$ and thawing, and quantity of homogenate added per assay on leucine catabolism. Initial results from kidney and liver were very similar, kidney and SM muscle only were used to complete the assay evaluation. Both leucine deamination and decarboxylation activity were linear up to $30 \mathrm{~min}$; the substrate saturation runs showed a plateauing at $1.5 \mathrm{~mm}$-leucine for both enzyme activities with a further moderate increase to $2.0 \mathrm{~mm}$-leucine. Adipose tissue was not assayed, but Tischler \& Goldberg (1980) reported that leucine deamination and decarboxylation were routinely obtained at $0.5 \mathrm{~mm}$-leucine with rat adipose tissue. Since the Michaelis-Menten constant $\left(K_{m}\right)$ values for BCAA amino-transferase range from 0.4 to $0.8 \mathrm{~mm}$-leucine in rats (Harper et al. 1984), and to ensure an ample supply of 4-methyl 2oxopentanoic acid for branched-chain 2-oxo acid dehydrogenase activity, especially in tissues where the aminotransferase may be rate-limiting (Harper et al. 1984), we adopted $2.0 \mathrm{~mm}$-leucine for all assays. 
The assay was found to be linear over the range $0.2-1 \cdot 0 \mathrm{ml}$ tissue homogenate. Under our conditions, protein per incubation ranged from 5 to $25 \mathrm{mg}$ for liver, muscle and kidney. For adipose tissue homogenates, protein per incubation was $2-8 \mathrm{mg}$.

Previous workers found that mitochondrial branched-chain acid 2-oxo dehydrogenases were extremely labile during preparative steps and particularly following freezing even in the presence of glycerol (Odessey \& Goldberg, 1979). The effect of cryogenic freezing in glycerol and thawing after storage from 2 to $6 \mathrm{~h}$ at $-70^{\circ}$ on leucine catabolism was assessed by us with kidney and SM muscle homogenates. Enzyme activities did not decline with storage time and were equal to values for fresh homogenates (Busboom, 1984).

\section{Analytical procedures}

Protein content of tissue homogenates was determined using Folin phenol reagent (Lowry et al. 1951).

\section{Statistical evaluation}

Values were analysed by one-way analysis of variance and significant differences, comparing the day 1 means to all other means, were determined with Dunnett's test (Gill, 1978).

\section{Radioisotopes and reagents}

$\left[1-{ }^{14} \mathrm{C}\right]$ leucine was obtained from Amersham and diluted in enzyme-assay incubation buffer. L-Leucine, thiamin pyrophosphate, 2-oxo-glutarate, dithiothreitol, and Folin and Ciocalteu's phenol reagent were obtained from Sigma Chemical Co., St Louis, MO, while all other reagents were of analytical grade and purchased from either J. T. Baker Chemical Co., Phillipsburg, NJ, or Sigma Chemical Co.

\section{RESULTS}

\section{Role of age on leucine catabolism}

Table 2 presents the results for the leucine deamination and decarboxylation assays for two skeletal muscles, liver, kidney and adipose tissue for the sheep from 1 to $365 \mathrm{~d}$ of age. All enzyme activities within tissues were compared with the day 1 value.

Because sheep in the present study were slaughtered in two consecutive years, 1982 and $1983,84-d$ leucine deamination and decarboxylation values for both years are presented in Table 2. The 1983 84-d values (shown in parentheses in Table 2) were not included in the statistical analyses. Overall, the 1982 and 1983 84-d values are quite comparable across all tissues and both enzymic activities.

Leucine deamination by longissimus muscle homogenates was highest $(P<0.01)$ in lambs on day 1 , lower by day 28 , and showed a moderate rise (not significant, $P>0.05$ ) at day 365. Longissimus muscle leucine decarboxylation activity exhibited the same general developmental profile as deamination, i.e. activity was highest in neonatal lambs $(P<0.01)$, lower at $28 \mathrm{~d}$, and then tended to increase slightly as the lambs matured. The effect of age on deamination in trapezius muscle was similar to longissimus muscle except for the extremely high activity at $365 \mathrm{~d}(P<0.01)$. Trapezius muscle in sheep at this age contains considerable quantities of intramuscular and intermuscular fat depots. The adipose depots may account for the elevated deamination. Leucine deamination activity in both longissimus and trapezius muscles was 7 - to over 100 -fold higher than the leucine decarboxylation activity (Table 2) suggesting that 4-methyl 2-oxopentanoic acid was not limiting branched-chain 2-oxo acid dehydrogenase in ovine muscle.

In liver homogenates, both deamination and decarboxylation activities tended to decrease after day 1 and then remained relatively constant from 28 to $365 \mathrm{~d}$. There was no 
Table 2. Leucine deamination and decarboxylation activity in tissue from sheep ${ }^{\dagger}$

(Mean values for five sheep except for day 365 when there were four sheep)

\begin{tabular}{|c|c|c|c|c|c|}
\hline $\begin{array}{l}\text { Age } \\
\text { (d) }\end{array}$ & $\begin{array}{l}\text { Longissimus } \\
\text { muscle }\end{array}$ & $\begin{array}{l}\text { Trapezius } \\
\text { muscle }\end{array}$ & Liver & Kidney & Adipose $\ddagger$ \\
\hline \multicolumn{6}{|c|}{ Leucine deamination } \\
\hline 1 & 246 & 173 & 181 & 279 & 929 \\
\hline 28 & $28^{* *}$ & 70 & 111 & 252 & 423 \\
\hline 56 & $26^{* *}$ & 64 & $37 * *$ & 246 & 417 \\
\hline 84 & $63^{* *}(31)$ & $105(71)$ & $93(59)$ & $610^{* *}(382)$ & ND \\
\hline 112 & $16^{* *}$ & 33 & $62 *$ & 448 & ND \\
\hline 140 & $17^{* *}$ & 66 & $38^{*}$ & 362 & ND \\
\hline 168 & $22^{* *}$ & 124 & 76 & 467 & ND \\
\hline 196 & $47^{* *}$ & 113 & 68 & $654^{* *}$ & ND \\
\hline 224 & $24^{* *}$ & 122 & 107 & 568 & ND \\
\hline 365 & $83^{* *}$ & $506^{* *}$ & $77^{*}$ & $495^{* *}$ & $4612^{* *}$ \\
\hline SE & 17 & 66 & 30 & 55 & 444 \\
\hline \multicolumn{6}{|c|}{ Leucine decarboxylation } \\
\hline 1 & 28 & 25 & 65 & 82 & 261 \\
\hline 28 & $2^{* *}$ & $6^{*}$ & $20 * *$ & 116 & $7 * *$ \\
\hline 56 & $1^{* *}$ & $3^{*}$ & $26^{* *}$ & 102 & $8^{* *}$ \\
\hline 84 & $<1^{* *}(1)$ & $<1^{* *}(2)$ & $46^{*}(32)$ & $306^{* *}(171)$ & ND \\
\hline 112 & $1^{* *}$ & 1 & $34 * *$ & $298 * *$ & ND \\
\hline 140 & $<1^{* *}$ & $1^{*}$ & $17^{* *}$ & $209^{* *}$ & ND \\
\hline 168 & $1 * *$ & $2^{*}$ & $36^{*}$ & $293^{* *}$ & ND \\
\hline 196 & $6^{* *}$ & $11^{*}$ & $27^{*}$ & $340^{* *}$ & ND \\
\hline 224 & $2^{* *}$ & $2^{* *}$ & $35^{*}$ & $245^{*}$ & ND \\
\hline 365 & $6^{* *}$ & $9^{*}$ & $38^{*}$ & $234^{*}$ & $27^{* *}$ \\
\hline $\mathrm{SE}$ & 2 & 3 & 6 & 23 & 6 \\
\hline
\end{tabular}

ND, not determined.

Mean values within a column were significantly different from control value (day 1 ): ${ }^{*} P<0.05,{ }^{* *} P<0 \cdot 01$.

$\dagger$ For details of procedures, see pp. 325-326

$\ddagger$ Day 1 perirenal adipose; days 28,56 and 265 subcutaneous adipose.

$\S$ Tissue homogenate.

Tay 84 values for year 1983 are given in parentheses, for comparison only; not included in statistical analysis.

consistent age effect on leucine deamination and decarboxylation in kidney homogenates; absolute activities in kidney homogenates were highest for decarboxylation and between those noted for deamination in adipose tissue and liver.

Leucine catabolism in adipose tissue was studied only in 1983 (year 2) at 1, 28 and 56 $\mathrm{d}$ of age, and with an extra slaughter group at $365 \mathrm{~d}$ of age. Perirenal adipose tissue was assayed for 1-d old lambs, but subcutaneous adipose tissues were used for all other ages. The perirenal adipose tissue from the lambs at 1-d-old had the visual appearance of brown adipose tissue. Others have shown that nearly $98 \%$ of the adipose tissue present in neonatal lambs had the cytological characteristics of brown adipose tissue (Oh et al. 1972; Vernon, 1980).

Adipose tissue deamination activity decreased from 1 to $28 \mathrm{~d}$ (not significant), but activity was significantly greater $(P<0.01)$ at $365 \mathrm{~d}$ than at all of the other ages studied. Leucine decarboxylation activities in adipose tissue homogenates were $261,7,8$ and $27 \mathrm{pmol}$ leucine degraded $\mathrm{mg}$ protein per $\min$ at $1,28,56$ and $365 \mathrm{~d}$ respectively. While subcutaneous adipose tissue deamination activity was 5 -fold greater at $365 \mathrm{~d}$ than for 
Table 3. Enzyme activity in tissues from sheep fed on three levels of protein and fasted for 48 or $96 h^{\dagger}$

\begin{tabular}{|c|c|c|c|c|c|c|c|c|}
\hline \multirow[b]{2}{*}{ Tissue } & \multicolumn{4}{|c|}{ Dietary protein $(\mathrm{g} / \mathrm{kg})$} & \multicolumn{4}{|c|}{ Duration of fast (h) $\ddagger$} \\
\hline & $12 \S$ & 8 & 18 & SE & $0 \S$ & 48 & 96 & $\mathrm{SE}$ \\
\hline \multicolumn{9}{|c|}{$\begin{array}{l}\text { Leucine deamination } \\
\text { mol/mg protein" per min) }\end{array}$} \\
\hline Longissimus muscle & 68 & 57 & 81 & 8 & 68 & 68 & 38 & 14 \\
\hline Trapezius muscle & 136 & 102 & 105 & 45 & 136 & 134 & 87 & 46 \\
\hline Liver & 68 & 67 & 86 & 8 & 68 & 87 & 54 & 12 \\
\hline Kidney & 703 & 739 & 705 & 70 & 703 & 659 & 550 & 61 \\
\hline Subcutaneous adipose & 5557 & $3\lfloor 44$ & 6218 & 1451 & 5557 & 4300 & 3049 & 817 \\
\hline \multicolumn{9}{|c|}{$\begin{array}{l}\text { Leucine decarboxylation } \\
\text { (pmol/mg protein }{ }^{1} \text { per min) }\end{array}$} \\
\hline Longissimus muscle & 3.4 & 1.0 & $8 \cdot 5^{*}$ & 1.6 & 3.4 & $4 \cdot 7 \uparrow$ & 1.5 & $1 \cdot 3$ \\
\hline Trapezius muscle & 3.0 & 4.8 & $9 \cdot 4^{* *}$ & $1 \cdot 4$ & $3 \cdot 0$ & 9.00 & 3.6 & $2 \cdot 0$ \\
\hline Liver & 46.9 & $42 \cdot 1$ & $56 \cdot 1^{*}$ & 3.0 & $46 \cdot 9$ & $43 \cdot 8$ & $21 \cdot 7^{*}$ & 5.6 \\
\hline Kidney & $544 \cdot 9$ & $376 \cdot 7$ & $415 \cdot 4$ & $63 \cdot 3$ & $544 \cdot 9$ & $456 \cdot 7$ & $284 \cdot 4^{*}$ & $73 \cdot 4$ \\
\hline Subcutaneous adipose & $240 \cdot 7$ & $144 \cdot 0$ & $322 \cdot 0$ & $78 \cdot 3$ & $240 \cdot 7$ & $218.8 \%$ & $261 \cdot 3 *$ & $42 \cdot 5$ \\
\hline
\end{tabular}

Mean values for different protein levels and for different periods of fast were significantly different from initial value: ${ }^{*} P<0.05,{ }^{* *} P<0.01$.

$\dagger$ For details of diets, see Table 1 and for procedures, see pp. 325-326.

$\$$ Duration of fast, $0 \mathrm{~h}$ was $12 \mathrm{~h}$ after feed removal the previous evening.

$\S 0 \mathrm{~h}$ fast and $120 \mathrm{~g}$ protein $/ \mathrm{kg}$ column are the same values.

\| Tissue homogenates.

I Mean for four sheep.

perirenal adipose at $1 \mathrm{~d}$, lambs at 1 -d-old had approximately 10 -fold greater adipose tissue decarboxylation activity than at $365 \mathrm{~d}$. The high decarboxylation activity observed in brown adipose tissue homogenates from the lambs at 1-d-old may be due to the abundance of mitochondria in this tissue (Allen et al. 1976). Adipose tissue deamination activity was 3.5 to 180-fold higher than decarboxylation activity indicating that 4-methyl 2oxopentanoic acid was not likely limiting assayable decarboxylation, especially in the older animals.

\section{Dietary protein effect on leucine catabolism}

Results from studies on the role of dietary protein concentration and length of fast are reported in Table 3 . Both sets of values are presented together since the $120 \mathrm{~g}$ protein $/ \mathrm{kg}$ group was also the $12 \mathrm{~h}$ overnight feed removal initial group for the fast study.

There were no differences $(P>0.05)$ in leucine deamination for any of the tissues studied in response to the three levels of dietary protein (Table 3 ). In each dietary-treatment group, adipose tissue had high, kidney intermediate, and liver and skeletal muscle low leucine deamination activities. In all cases trapezius muscles had higher deamination activities than longissimus muscles. Leucine decarboxylation tended to increase with the amount of protein fed for all tissues except kidney, and leucine decarboxylation activities in the longissimus muscle and liver were significantly higher $(P<0.05)$ in lambs fed on the $180 \mathrm{~g}$ protein $/ \mathrm{kg}$ diet compared with the $120 \mathrm{~g}$ protein $/ \mathrm{kg}$ control group. The enzyme activities in animals fed on $80 \mathrm{~g}$ protein $/ \mathrm{kg}$ did not differ from those of the control group (Table 3). Kidney homogenates exhibited the highest decarboxylation activity followed, in descending order, by adipose tissue, liver, trapezius and longissimus muscles for all dietaryprotein groups. 


\section{Effect of fasting on leucine catabolism}

Length of fast ( 48 or $96 \mathrm{~h}$ ) had little effect on leucine deamination (Table 3) with our assay conditions in adipose, muscle and kidney homogenates, but in all cases the activity tended to remain constant or rise after $48 \mathrm{~h}$ and then decline to below initial levels by $96 \mathrm{~h}$. Leucine decarboxylation in muscle homogenates remained unchanged up to $96 \mathrm{~h}$ of fast; however, decarboxylation activity declined $(P<0.05)$ in adipose, kidney and liver homogenates after a $96 \mathrm{~h}$ fast (Table 3 ).

\section{DISCUSSION}

In non-ruminants, muscle tissue is considered the major site of catabolism of isoleucine, leucine and valine (Walser \& Williamson, 1981; Harper et al. 1984). In contrast, BCAA catabolism by peripheral tissues of sheep seems to be significantly less than that in nonruminants (Lindsay, 1982; Ballard et al. 1976; Goodwin et al. 1987). Bergman and coworkers (Bergman et al. 1974; Heitman \& Bergman, 1981) showed that in fed sheep the liver removes approximately $40 \%$ of all BCAA absorbed from the small intestine into the blood while the remaining $60 \%$ was removed by peripheral tissues, mainly muscle and others such as adipose tissue, brain and lungs (Pell \& Bergman, 1983; Pell et al. 1983a,b). This group of workers further showed that BCAA are deaminated to branched-chain 2-oxo acids, some of which may be oxidized to $\mathrm{CO}_{2}$ for energy production (Pell \& Bergman, 1983). During fasting, however, hepatic removal rate of BCAA is maintained by sheep and the major source of these amino acids is now skeletal muscle. During fasting branchedchain 2-oxo acid release from skeletal muscle is maintained or even increased (Pell et al. $1983 \mathrm{~b}$ ). Other workers have emphasized the unique role and quantitative importance of extensive leucine oxidation in muscle during fasting toward meeting energy needs in nonruminants (Goldberg \& Tischler, 1981).

\section{Enzyme assays}

To explore some of the reasons for these apparent differences in the role of various tissues in BCAA catabolism between sheep and non-ruminants, the present studies were initiated to assess the enzymic basis in skeletal muscle, adipose tissue, liver and kidney of leucine catabolism. Our approach was to determine maximal activity or capacity for leucine deamination and decarboxylation in vitro, thereby disregarding metabolic control by covalent modification of branched-chain 2-oxo acid dehydrogenase in vivo.

The key concern about these results is the appropriateness of the enzyme assay procedures. Of particular concern are the freezing of tissue homogenates and storage before assays, use of leucine as substrate for both the deamination and decarboxylation assays, the extreme labileness of branched-chain 2-oxo acid dehydrogenase, and the effectiveness of the pre-incubation to deplete ATP and convert the branched-chain 2-oxo acid dehydrogenase complex into the fully active state. Busboom (1984) and Paxton et al. (1986) showed that freezing had little effect on leucine catabolic enzyme activities. The use of leucine as substrate for both assays can markedly affect observed decarboxylation activities if the amount of substrate for that reaction, 4-methyl 2-oxopentanoate, is well below the $K_{m}$ for the dehydrogenase complex. Our results indicate that for longissimus and trapezius muscles and subcutaneous adipose tissue, the deaminating activities were 10- to 20-fold greater than decarboxylating activities and 4-methyl 2-oxo pentanoic acid was most likely not limiting. The decarboxyation results obtained in liver and kidney with our assay system may be underestimated. Subsequent work with this assay system, employing 4-methyl 2-oxopentanoic acid as substrate at $0.5 \mathrm{~mm}$, showed that decarboxylating activities were 
Table 4. Estimated capacity of leucine deamination and decarboxylation in tissues of sheep at three ages*

\begin{tabular}{|c|c|c|c|}
\hline Age (d)... & 1 & 56 & 365 \\
\hline Live wt $(\mathrm{kg})$ & 4.9 & $27 \cdot 2$ & $121 \cdot 4$ \\
\hline $\begin{array}{l}\text { Skeletal muscle }(\mathrm{kg}) \dagger \\
\text { Sarcoplasmic protein }(\mathrm{g} / \mathrm{kg}) \\
\text { Sarcoplasmic protein }(\mathrm{g}) \\
\text { Deamination }(\mathrm{mmol} / \mathrm{min}) \\
\text { Decarboxylation }(\mathrm{mmol} / \mathrm{min})\end{array}$ & $\begin{array}{l}0.94 \\
32 \\
30 \cdot 0 \\
7 \cdot 38 \\
0.84\end{array}$ & $\begin{array}{c}7 \cdot 53 \\
41 \\
309 \cdot 7 \\
8 \cdot 06 \\
0 \cdot 47\end{array}$ & $\begin{array}{c}31 \cdot 6 \\
42 \\
1327 \cdot 2 \\
110 \cdot 39 \\
9 \cdot 31\end{array}$ \\
\hline $\begin{array}{l}\text { Liver }(\mathrm{kg}) \\
\text { Protein }(\mathrm{g} / \mathrm{kg}) \\
\text { Liver protein }(\mathrm{g}) \\
\text { Deamination }(\mathrm{mmol} / \mathrm{min}) \\
\text { Decarboxylation }(\mathrm{mmol} / \mathrm{min})\end{array}$ & $\begin{array}{c}0.09 \\
211 \\
19 \cdot 0 \\
3 \cdot 44 \\
1 \cdot 24\end{array}$ & $\begin{array}{l}0.55 \\
276 \\
151 \cdot 8 \\
5.62 \\
3.95\end{array}$ & $\begin{array}{l}1 \cdot 48 \\
255 \\
377 \cdot 4 \\
29 \cdot 06 \\
14 \cdot 34\end{array}$ \\
\hline $\begin{array}{l}\text { Kidney }(\mathrm{kg}) \\
\text { Protein }(\mathrm{g} / \mathrm{kg}) \\
\text { Kidney protein }(\mathrm{g}) \\
\text { Deamination }(\mathrm{mmol} / \mathrm{min}) \\
\text { Decarboxylation }(\mathrm{mmol} / \mathrm{min})\end{array}$ & $\begin{array}{c}0.03 \\
146 \\
4 \cdot 4 \\
1 \cdot 23 \\
0 \cdot 36\end{array}$ & $\begin{array}{c}0.11 \\
159 \\
17 \cdot 5 \\
4 \cdot 31 \\
1.79\end{array}$ & $\begin{array}{c}0.23 \\
172 \\
39 \cdot 6 \\
19 \cdot 6 \\
9 \cdot 86\end{array}$ \\
\hline $\begin{array}{l}\text { Adipose }(\mathrm{kg}) \ddagger \\
\text { Protein }(\mathrm{g} / \mathrm{kg}) \\
\text { Adipose protein }(\mathrm{g}) \\
\text { Deamination }(\mathrm{mmol} / \mathrm{min}) \\
\text { Decarboxylation }(\mathrm{mmol} / \mathrm{min})\end{array}$ & $\begin{array}{c}0.03 \\
24 \\
0.7 \\
0.65 \\
0.18\end{array}$ & $\begin{array}{l}1 \cdot 16 \\
41 \\
47 \cdot 6 \\
19 \cdot 85 \\
0.38\end{array}$ & $\begin{array}{c}14 \cdot 1 \\
36 \\
507 \cdot 6 \\
2341 \cdot 65 \\
13 \cdot 71\end{array}$ \\
\hline
\end{tabular}

- All tissue weights and chemical analyses are the means of five sheep (Busboom, 1984).

$\uparrow$ Skeletal muscle $=$ longissimus muscle divided by 0.095 (Kaufman et al. 1963).

† Day 1 total dissectable perirenal fat, days 56 and 365 subcutaneous fat. Value (days 56 and 365 ) does not include inter-and intramuscular fat and represents approximately half the total body fat.

somewhat higher than those observed here but always lower than leucine aminotransferase activities (Busboom, 1984).

The present results show that particularly in skeletal muscle (specifically longissimus muscle) in sheep, leucine aminotransferase activity is only moderate while leucine decarboxylation was very low. Results also indicate that the adipose tissue, among the peripheral tissues, had high aminotransferase activity but kidney and liver had the highest capacity for leucine decarboxylation.

\section{Role of various tissues in whole-body leucine catabolism}

Harper et al. (1984) have emphasized the importance of skeletal muscle (peripheral tissue) and liver in leucine transamination and 4-methyl 2-oxopentanoic acid oxidation respectively, in rodents. Results from in vivo tracer kinetic studies in sheep (Pell \& Bergman, 1983; Pell et al. 1983a,b, 1986) imply a quantitatively larger role for liver in leucine metabolism than skeletal muscle. It is indeed hazardous to apply in vitro enzyme activity findings to any in vivo situation. But the present results may be viewed in the following context; if actual live weights and weights of various tissues are known for sheep at various ages, these in vitro results may be applied to estimate potential leucine catabolism capacity in various tissues and physiological states. Table 4 presents such estimates for both leucine deamination and decarboxylation. The highest estimated deamination capacity is in skeletal muscle, followed by liver, kidney and perirenal adipose tissue for day 1 lambs. At this age, liver shows the highest estimated leucine decarboxylation 
capacity and perirenal adipose tissue the lowest. By weaning (56 d), subcutaneous adipose tissue (about half the total body lipid) accounts for half the estimated deamination capacity, followed by muscle, liver and kidney. Liver has over half the estimated decarboxylation capacity, while skeletal muscle and subcutaneous adipose contributed little to this activity at weaning. Estimated deamination capacity is found almost totally in adipose tissue, while liver and kidney account for half the estimated decarboxylation capacity in 1-year-old sheep.

Dietary protein level had little or no impact on the pattern of tissue capacity for leucine deamination and decarboxylation capacity. In ruminating sheep, an $80 \mathrm{~g}$ protein $/ \mathrm{kg}$ diet is not severely limiting because of rumen- $\mathrm{N}$ recycling and microbial re-incorporation, while the $180 \mathrm{~g}$ protein $/ \mathrm{kg}$ diet most likely resulted in little extra amino acid uptake in the small intestine compared with the $120 \mathrm{~g}$ protein $/ \mathrm{kg}$ diet (Owens \& Bergen, 1983). Thus this experiment does not fully clarify the role of dietary protein intake (e.g. intestinal amino acid uptake) in leucine catabolism in sheep.

The results in Table 3 indicate that after a 48 and $96 \mathrm{~h}$ fast, skeletal muscle is not a major site of leucine catabolism and oxidation to supply energy to the muscle. These results indicate a diversity in the site of leucine metabolism between sheep (ruminants) and nonruminants and are in agreement with whole-body tracer kinetic studies indicating that in sheep, leucine flows from the periphery (muscle) to the visceral organs (liver) for catabolism on fasting.

This work was supported by the Michigan Agricultural Experiment Station and is released as Journal Article no. 11510.

\section{REFERENCES}

Ahmed, B. M., Bergen, W. G. \& Ames, N. K. (1983). Journal of Nutrition 113, 1529-1543.

Allen, L. E., Beitz, D. C., Cramer, D. A. \& Kaufman, R. G. (1976). Biology of Fat in Meat Animals, North Central Regional Research Publication no. 234. Madison, WI:University of Wisconsin.

Ballard, F. J., Filsell, O. H. \& Jarrett I. G. (1976). Metabolism 25, 415-418.

Bergman, E. N., Kaufman, C. F. Wolff, J. E. \& Williams, H. H. (1974). American Journal of Physiology 226, 833-837.

Busboom, J. R. (1984). Effect of age and nutritional state on branched chain amino acid degradation in sheep. PhD Thesis, Michigan State University, East Lansing, MI, USA.

Chang, T. W. \& Goldberg, A. L. (1978a). Journal of Biological Chemistry 253, 3677-3684

Chang, T. W. \& Goldberg, A. L. (1978 b). Journal of Biological Chemistry 253, 3685-3695.

Gill, J. L. (1978). Design and Analysis of Experiments, Vol. I, pp. 183-186. Ames, Iowa: Iowa State University Press.

Goldberg, A. L. \& Odessey, R. (1972). American Journal of Physiology 223, 1384-1391.

Goldberg, A. L. \& Tischler, M. E. (1981). In Metabolism and Clinical Implications of Branched and Keto Acids. pp. 73-78 [M. Walser and J. R. Williams, editors]. Amsterdam: Elsevier/North Holland.

Goodwin, G. W., Gibboney, W., Paxton, R., Harris, R. A. \& Lemons, J. A. (1987). Biochemical Journal 242, 305-308.

Heitman, R. N. \& Bergman, E. N. (1981). American Journal of Physiology 241, E465-E472.

Harper, A. E., Miller, R. H. \& Block, K. P. (1984). Annual Review of Nutrition 4, 409454.

Kasperik, G. J., Dohm, G. L. \& Snider, R. D. (1985). American Journal of Physiology 248, R166-R171.

Kaufman, R. G., St Clair, L. E. \& Reger, R. J. (1963). Ovine Myology, Illinois Agricultural Experiment Station Bulletin no. 693, pp. 52-53. Urbana, IL, USA: University of Illinois.

Lindsay, D. B. (1982). Federation Proceedings 41, 2550-2554.

Lindsay, D. B. \& Buttery, P. J. (1980). In Protein Deposition in Animals, pp. 125-146 [P. J. Buttery and D. B. Lindsay, editors]. London: Butterworth.

Lowry, O. H., Rosebrough, N. J., Farr, A. L. \& Randall, R. J. (1951). Journal of Biological Chemistry 193, $265-275$.

National Research Council (1975) Nutrient Requirements of Sheep, 5th revised ed. Washington DC: National Academy of Sciences.

Odessey, R. \& Goldberg, A. L. (1979). Biochemicial Journal 178, 475-489.

Oh, J. H., Hume, I. D., \& Torrel, D. T. (1972). Journal of Animal Science 35, 450-459. 
Owens, F. N. \& Bergen, W. G. (1983). Journal of Animal Science 57, Suppl. 2, 498-518.

Paxton, R., Kuntz, M. \& Harris, R. A. (1986). Archives of Biochemistry and Biophysics 244, $187-201$.

Pell, J. M. \& Bergman, E. N. (1983). American Journal of Physiology 244, E282-E289.

Pell, J. M., Caldarone, E. M. \& Bergman, E. N. (1983a). Biochemical Journal 214, 1015-1018.

Pell, J. M., Caldarone, E. M. \& Bergman, E. N. (1983b). Federation Proceedings 42, 815, Abstr.

Pell, J. M., Caldarone, E. M. \& Bergman, E. N. (1986). Metabolism 35, $1005-1016$.

Teleni, E, Annison, E. F.., Lindsay, D. B. \& Mackenzie, J. (1983). Proceedings of the Nutrition Society, 42, 92A.

Tischler, M. E. \& Goldberg, A. L. (1980). Journal of Biological Chemistry 257, 1613-1621.

Vernon, R. G. (1980). Progress in Lipid Research 19, 23-106.

Wagenmakers, A. J. M. \& Veerkamp, J. H. (1982). Biochemical Medicine 28, 16-31.

Walser, M. \& Williamson, J. R. (1981). Metabolism and Clinical Implications of Branched Chain Amino and Keto Acids. Amsterdam: Elsevier/North Holland. 